\title{
Teaching Vocabulary Acquisition through Derivational Suffixes of SMP Santo Petrus Medan in the Academic Year 2017/2018
}

\author{
Karisma Erikson Tarigan ${ }^{\mathbf{1}}$, Margaret Stevani \\ ${ }^{1}$ Catholic University of Saint Thomas Medan \\ erick_tarigan2006@yahoo.com
}

\begin{abstract}
This study is aimed to improve the students' vocabulary acquisition through derivational suffixes strategy. The subject of this study is the students of Class IX-1 of SMP Santo Petrus Medan in the academic year of 2017/2018. This study is conducted by applying Classroom Action Research (CAR), which have been conducted in two cycles (cycle 1 and cycle 2) and each cycle consisted of four meetings. The results of vocabulary test shows that the progressing mean score of the pretest is 34.66, post test in cycle 1 is 93.46, and post test in cycle 2 is 97.33. In cycle 1 , the comparison percentage of nominal is $88.83 \%$, verbal is $77.46 \%$, adjectival is $40.74 \%$, and adverbial is $84.14 \%$. In cycle 2 , the comparison percentage of nominal is $100 \%$, verbal is $95.45 \%$, adjectival is $65.84 \%$, and adverbial is $94.91 \%$. The percentage of the students who pass Minimal Criterion Mastery in each cycle is $100 \%$, with the improvement $169.64 \%$ in cycle 1 to $180.81 \%$ in cycle 2. These indicate that there is a significant improvement of the students' vocabulary mastery through affixation strategy of Class IX-1 of SMP Santo Petrus Medan in the academic year of 2017/2018.
\end{abstract}

Keywords

vocabulary mastery; affixation strategy; derivational suffixes; Classroom Action Research

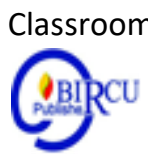

\section{Introduction}

Vocabulary mastery has an important role in English. It is the fundamental element to acquire English basic competences such as listening, speaking, reading, and writing. Thornbury (2002:13) states that without grammar very little can be conveyed, without vocabulary nothing can be conveyed. It is similar to Injeeli (2013:8) stating that if language structures make up the skeleton of language, then it is vocabulary that provides the vital organs and the flesh. Based on the statements, students will not able to say or write anything in English if they do not have an extensive vocabulary. The ability to use the structures and functions of grammar are useless if students do not have the sufficient vocabulary that is needed to convey exactly what they mean. Besides that, one function of vocabulary is building every sentence in a language. This is accurate because the fluency of students in learning English can be seen from how much vocabulary they have and how they can use it in a meaningful way.

One most striking attribute as human being is our ability to use language. The study of the nature of language and how language is used are defined as linguistic. The major thing to see the existence of a language is through words. It is almost impossible to learn a language without words because the communication between human beings is based on words. It means that the word has its rule to use the language efficiently. It is categorized as morphology. Morphology is the study of the internal structure of words and the rules of word formation in a language. By learning morphology, students will be able to understand how words enter a language, what they consist of, and how they are formed by combining 
prefixes, suffixes, and roots. Consequently, morphology can be a valuable instructional tool for students to develop and use vocabulary creatively. Nijakowska (2010:175) states that morphology focuses on how words are structured from constituent parts. Many words can be divided into smaller units - morphemes, which constitute the smallest linguistic units with a meaning (e.g. unhappy, unlucky, unsatisfied). Some words cannot be further broken down (e.g. car), they are free morphemes since they can stand alone, while bound morphemes (-un, -s, or -ed) are always attached to some other morphemes. Bound morphemes can be divided according to their function in complex words, into derivational and inflectional morphemes. Based on the examples, a word is usually added by a bound morpheme. It is called affixation. Affix can recombine morpheme to construct new meaning by means of morphology.

Learning vocabulary is closed to a grammatical element within a word, that is affixation. Nation (2001:63) states that knowing a word can involve knowing that it is made up of affixes and a stem that can occur in other words. It is supported by Karimkhanlooei and Maboudi (2017:76) stating that one way through which students can improve their vocabulary knowledge is mastering the knowledge of word building devices such as affixes. Kim (2013:45) states that the implementation of morphological competence in derivational affixation learning improves students' vocabulary acquisition. Based on these theories, affixation in derivational morpheme can assist students to construct a new vocabulary.

Derivational affixation can occur with unlimited set of words. Adeniyi, et. al. (2010:23) state that derivational morpheme is a type of bound morpheme which generates or creates new words by either changing the class of word or forming a new word. Jackson and Amvela (2007:88) state that class-changing derivational affixes, once added to a stem, form a derivative which is automatically marked by that affix as noun, verb, adjective, or adverb. For instance, by adding a suffix to beauty (noun) can be analyzed as the following.

$$
\begin{aligned}
& \text { 1. } \frac{\text { Beauty }}{\text { Root (noun) }}+\frac{f y}{\text { Suffix }}=\frac{\text { Beautify }}{\text { Verb }} \\
& 2 . \\
& \frac{\text { Beauty }}{\text { Root (noun) }}+\frac{f u l}{\text { Suffix }} \quad=\frac{\text { Beautiful }}{\text { Adjective }} \\
& \text { 3. } \frac{\text { Beauty }}{\text { Root (noun) }}+\frac{f u t}{\text { Suffix }}+\frac{b y}{\text { Suffix }}=\frac{\text { Beautifully }}{\text { Adverb }}
\end{aligned}
$$

Relevant researches had been done to examine affixation in improving vocabulary. The first research was conducted by Bhatti, et. al. (2016) in their journal entitled "Improving Vocabulary through Affixes at Secondary Level". They state that the use of affixes strategy gives a significant improvement in vocabulary. It is statistically had been proven by the increase of the students' mean score in posttest which is higher than the mean score in pretest. The mean score increased from 64.04 in pretest to 68.21 in posttest. The second research was conducted by Kim (2013) entitled "Vocabulary Acquisition with Affixation: Learning English Words based on Prefixes and Suffixes" stating that affixation strategy can help students learn English vocabulary mastery much faster.

Teaching vocabulary is not a simple task. Almost everyone realizes that teaching vocabulary only wastes time because vocabulary number is unlimited. Dealing with the fact, one possible way to broaden vocabulary is by using affixation. Most of affixation can be found in an English text. Based on the writer's observation in SMP Santo Petrus Medan, it was found out that those students had difficulties in learning vocabulary. They made mistakes in interpreting the meaning of word in the sentence because it contains an affix. They seldom realized that the meaning could change based on its part of speech. It happened because students had less knowledge of word family. For example:

$$
\text { 1. } \frac{\text { Clear }}{\text { noun }}>\frac{\text { Clearly }}{\text { adverb }}=\text { Jelas (False Interpretation) }
$$


2. $\frac{\text { Informer }}{\text { noun }}><\frac{\text { Inform }}{\text { verb }}><\frac{\text { Informative }}{\text { adjective }}=$ Informasi (False Interpretation)

3. Powerless $><\frac{\text { Powerful }}{\text { adjective }}><\frac{\text { Powerfully }}{\text { adjective }}=$ Kuat (False Interpretation)

Furthermore, some of students said that they felt difficult in memorizing vocabularies. There were only limited numbers still remained. The traditional method was usually used by looking for difficult words, found the meaning in the dictionary, and students supposed to memorize new words that they heard or read in an English textbook. It made students bored and unmotivated with English subject. If they can use affix as the subpart of word, they can acquire the number of new vocabularies and their meanings because almost words can be easily linked by determining the word class.

Considering the facts, the writer also conducted the pre-test about vocabulary mastery to the students of Class IX-1 of SMP Santo Petrus Medan. Based on the result of pre-test, all the students of the ninth grade could not pass Minimal Criterion Mastery in English subject whose value is 70 .

Based on the influence of vocabulary in affixation and its urgency in English curriculum, the writer decided to conduct a study entitled "Improving the Students' Vocabulary Mastery through Affixation Strategy."

\section{Review of Literature}

\subsection{Vocabulary}

Vocabulary is related to the meaning of words. Daller, et. al. (2016:245) state that vocabulary knowledge is seen as comprising knowledge about form, meaning, and use. Rasinski, et. al. (2008:13) state that vocabulary is knowledge of word meanings. Nation (2001:266) states that word parts are a very common and important aspect of English vocabulary. Oz (2014:85) states that when discussing about words, we sometimes make an important distinction between two types of words: content words and function words. Examples of content words include nouns, verbs, adjectives, and adverbs. They are also called open-ended or open-class words because we can frequently add new words to this class of words. Verspoor and Sauter (2000:88) state that nouns, verbs, adjectives and adverbs are very clearly open classes because new members are added almost every day. Based on these theories, noun, verb, adjective, and adverb are functioning to form a new vocabulary because they carry the meaning of the word.

Building vocabulary cannot be separated from affixation or morpheme. One way to affect vocabulary is affixation. Rasinski, et. al. (2008:44) state that knowing that words can be broken down into meaningful units is an important and powerful first step in vocabulary development. Cain (2010:100) states that vocabulary concerns the knowledge we have about the word meanings, morphology concerns our knowledge about word structure, specifically morphemes; which are the smallest units of meaning within words. Thus, both concern comprehension of words.

\subsection{Vocabulary Acquisition}

Peukert (2015:129) states that in second language acquisition, knowledge of derivational morphology and the combinatory properties of affixes and bases in second language acquisition has a positive effect on learners' receptive and productive vocabulary. 
Word formation involves a number of processes to create new words and to expand the vocabulary of a language. Lieber and Stekauer (2014:45) states that most derivational affixes in English are not acquired until after children enter elementary school, and some are only mastered once children have access to another source of information besides speech about the relations between such pairs, as danger-dangerous, library-librarian, or volcano-volcanic. What children acquire when also depends on which language they are learning. In some languages, derivation is king for the construction of new words.

\subsection{Morphology}

Morphology is a branch of linguistic of how words are attached together in a language. It is linked with the systematic form and meaning correspondences in vocabulary. Haspelmath and Sims (2010:2) state that morphology is the study of systematic co-variation in the form and meaning of words. Vadasy and Nelson (2012:108) state that morphological analysis also contributes importantly to the growth in students' vocabulary. Students can be taught to break an unfamiliar word into parts, to identify the meaning of each part, and then to put the parts back together to arrive at a words' meaning. Morphology is the ability to understand how words are formed through morpheme. Dechaine, et. al. (2012:77) state that the goal of morphology is to find minimal units of meaning - morphemes - and to understand how these units combine to form words. Hair (2008:42) states that morphology is the ability to gain information about the meaning of new words by looking at prefixes, roots, and suffixes.

\section{a. Morpheme}

Morpheme is the part of morphology. It increases knowledge of vocabularies. Oakhill, et. al. (2015:60) state that one source of this impressive gain in vocabulary knowledge is access to the constituent units of meaning (morphemes) in words. Traxler (2012:1924) states that words are made up of one or more morphemes. Plag (2002:25) states that the most important characteristic of the traditional morpheme is that it is conceived of as a unit of form and meaning. Lems, et. al. (2010:94) state that affixes are morphemes but they are not words and they cannot stand on their own. Denham and Lobeck (2010:149) state that morphemes, like words, fall into different classes. Morphemes are either bound or free. The words drink, cat, and butter are all free morphemes; they are single morphemes (mono-morphemic) and can stand alone as words. Bound morphemes themselves come in different types: -ize is a suffix, and un- is a prefix. Suffixes and prefixes fall under the more general heading of affixes, morphemes that attach to other morphemes or words by a process called affixation.

\section{b. Root}

Rasinski, et. al. (2008:12) state that using roots to unlock word meanings will do more than expand students' vocabularies. They state that when we teach vocabulary based on roots rather than word lists, we encourage our students to search for a word's meaning from the meaning of its root. Root consists of only noun, verb, adjective, and adverb. These belong to the open classes or contents word because it hold the meaning itself. Lee, et. al. (2015:77) state that basic parts of speech classes includes nouns, verbs, adjectives, and adverb. These words belong to open classes because they can be extended by means of word-formation. Adams (2014:113) states that the productive formation of new words in English is usually taken to be word-based, that is the base of a regularly formed new complex word must be able to occur also as an independent member of a major word class - noun, adjective, or verb. For example, defend: defensive, curious, curiousity. Rasinski, et. al. (2008:26) state that root 
is a part of a word that carries meaning. This simply means that a root is a word part that means something. It is a group letters with meaning.

\subsection{Derivational Suffixes}

Affixation is the process adding a morpheme to root to form a new word. Adebileje (2013:1757) states that a process where new words are formed through the addition of morphemes is referred to as affixation. Katamba (2015:54) states that derivation enables us to add new lexical items to the open word classes of noun, adjective, verb, and adverb. These are the classes that contain the so-called content word. Bara (2010:3) states that derivation is used to form new lexical items to word classes like nouns, verbs, adjectives, and adverbs. Derivational suffixes are the most affixes which change the class and the meaning of words. Huddleston and Pullum (2005:284) state that most category-changing affixes are suffixes. Plag (2002:109) states that the suffixes of English can be classified into the following groups: nominal, verbal, adjectival, and adverbial.

\section{a. Nominal Suffixes}

Plag (2002:109) states that nominal suffixes are often employed to derive abstract nouns from verbs, adjectives and nouns. For example:

(-age) : to express an activity (coverage, spillage), a collective entity (acreage, voltage), to state location (orphanage)

$\begin{array}{ll}\text { (-al) } & : \text { the result of an action (arrival, recital, referral) } \\ \text { (-ance), (-ence) } & : \text { action(absorbance, dependence) } \\ \text { (-ancy), (-ency) } & : \text { action(expectancy, dependency) } \\ \text { (-ant) } & : \text { an agent (applicant, defendant) } \\ \text { (-cy) (-ce) } & : \text { state or quality (agency, emergence) } \\ \text { (-dom) } & : \text { collective entity (professordom, studentdom) } \\ \text { (-ee) } & : \text { one who (employee) } \\ \text { (-eer) } & : \text { active or volitional participants in an event (teacher, singer) } \\ \text { (-er) } & : \text { location (bakery, brewery) } \\ \text { (-ry) } & : \text { established noun (stewardess) } \\ \text { (-ess) } & : \text { measure partitive nouns (cupful, handful) } \\ \text { (-ful) } & : \text { state (adulthood, childhood) } \\ \text { (-hood) } & : \text { person having to do with (technician, historian) } \\ \text { (-an) } & : \text { results of process (production, sedimentation) } \\ \text { (-ion) } & : \text { attitude, belief or theory (ballonist, careerist) } \\ \text { (-ism) } & : \text { denoting quality, state or property (curiosity, productivity) } \\ \text { (-ist) } & : \text { process or result (assessment, endorsement) } \\ \text { (-ity) } & : \text { state, condition (friendship, membership) } \\ \text { (-ment) } & \end{array}$

\section{b. Verbal Suffixes}

Plag (2002:116) states that there are four suffixes which derive verbs from other categories (mostly adjectives and nouns), namely -ate, -en, -ify and -ize.

(-ate) : provide with, make into (methanate, activate)

(-en) : make more (blacken, broaden)

(-ify) : locative, ornative, causative (trustify, humidify)

(-ize) : locative, ornative, causative (memorize, hospitalize) 


\section{c. Adjectival Suffixes}

$\begin{array}{ll}\text { (-able) } & \text { : capable of being (fashionable, agreeable) } \\ \text { (-al) } & \text { : result of an action (federal, institutional) } \\ \text { (-ary) } & \text { : having a tendency or purpose (complementary, evolutionary) } \\ \text { (-ed) } & \text { : having, being provided with (broad-minded, wooded) } \\ \text { (-esque) } & \text { : in the manner or style of (picturesque, Kafkaesque) } \\ \text { (-ful) } & \text { : having, being characterized by (beautiful, insightful) } \\ \text { (-ic) } & \text { : related to art or science (economical, historical) } \\ \text { (-ish) } & \text { : convey the concept of somewhat (clearish, freeish) } \\ \text { (-ive) } & \text { : having, being(connective, explosive) } \\ \text { (-less) } & \text { : without (hopeless, speechless) } \\ \text { (-ly) } & : \text { in the manner of, like an (brotherly, daughterly) } \\ \text { (-ous) } & \text { : processing (curious, barbarous) }\end{array}$

\section{d. Adverbial Suffixes}

Plag (2002:122) states that suffix -ly is appended to nouns and adjectives. With base nouns denoting persons, -ly usually conveys the notion of in the manner of $\mathrm{X}$ or like an $\mathrm{X}$, as in brotherly, daughterly, fatherly, womanly. Other common types of derivative have bases denoting temporal concepts (e.g. half-hourly, daily, monthly) or directions (easterly, southwesterly). Katamba (2005:46) states that adjective forms adverb from adjectives. For example: -ly (usually, busily, proudly, loudly, gratefully),-wise (crosswise).

\subsection{The Procedures of Teaching Vocabulary through Affixation Strategy}

Nation (2001:64) states that an important vocabulary learning strategy is using word parts to help remember the meaning of a word. This strategy requires learners to know the most frequent and regular affixes well, to be able to recognise them in words, and to be able to re-express the meaning of the word using the meanings of its word parts. Nation (2001:437) states that there are four aspects of word building knowledge that are worth monitoring by a teacher as follows:

1. The learners need to be able to recognize word parts in words,

a. The learners are given words that they break up,

b. The learners group words according to the parts,

2. The learners need to be able to recognize what the affixes mean and do,

a. The learners are given a list of word parts and have to write their meaning or function,

b. These parts could be presented in words,

3. The learners need to be aware of the changes of written and spoken form that occur when an affix is added to a word,

a. The simplest ways to test the written form is to give spelling dictation. That is, the teacher says words like unhappiness and the learners write them,

b. The teacher gives the learners a lists of stems + affixes which the learners must combine, and

4. The learners need to know which classes of stems can take certain affixes.

The writer taught the students about derivational suffixes in nominal (-er, -or, -ion), verbal (-en, -ize), adjectival (-ness, -less, -ful, -able), and adverbial (-ly) which form vocabulary in noun, verb, adjective, and adverb. The following was the explanation of each suffix which was taught by the writer:

1. Nominal Suffixes:-or, -ion, and -er 
Lindstrom (2007:142) when a word ends with a silent e, drop the e before adding a suffix that begins with a vowel (bake-baker). Hendrty et. al. (2010:33) state that when you add a suffix beginning with a vowel to a word whose final vowel is long, (as a result of the silent $\mathrm{e}$ at the end of the word), drop that e before you add the suffix (white + er $=$ whiter).

2. Verbal Suffixes : -en and -ize

Lutrario (2005:16) states that the endings -te, -en, -ify, and -ise, usually indicates that a word is a verb. Often, they can be added as suffixes to nouns and adjectives to change them into verbs: darken, classify, apologise. The spelling of the root word changes according to the rules which pupils will be familiar with from work in other contexts:

a. Ends with y: change $-\mathrm{y}$ to $-\mathrm{i}$ : category $\rightarrow$ categorise,

b. Ends with e: drop the e: wide $\rightarrow$ widen, mobil $\rightarrow$ mobilise, and

c. Ends with a single consonant preceded by a short vowel: double the final consonant: flat $\rightarrow$ flatten.

3. Adjectival Suffixes

a. -ness : Rhoades (2004:55) states that the suffix -ness begins with the consonant $n$. When the suffix -ness is added to the base word, ending in silent e, the e is not dropped. The suffix - ness adds one syllable to the base word.

b. -less : Rhoades (2004:56) states that when a words ends in a silent e, and the suffix -less is added, the silent e is not dropped. The suffix -less adds one syllable to a word.

c. -ful : Rhoades (2004:55) states that when the suffix -ful is added to the word taste, the silent e is not dropped. The suffix -ful adds one syllable to a word.

d. -able : Rhoades (2004:1) states that when the base word ends in a silent e and the suffix begins with a vowel, the e is dropped before adding the suffix (cure $\rightarrow$ curable).

4. Adverbial Suffix: -ly

Rhoades (2007:46) states that when the suffix -ly is added to a base word, it adds one syllable.

\subsection{The Advantages of Affixation Strategy}

Nation (2001:422) states that a knowledge of affixes and roots has two values for a learner of English. It can be used to help the learning of unfamiliar words by relating these words to known words or to known prefixes and suffixes, and it can be used as a way of checking whether an unfamiliar word has been successfully guessed from context. Hasani, et. al (2014:86) state that learning vocabulary through affixes which enables students to both deepen their present word knowledge and to better understand unknown words. Hatch, et. al. (2001:268) state that the affixes thereby help us to identify relationships within words. Klingner, et. al. (2015:115) state that affixes are especially important and provide a key to word meaning. Oz (2014:104) states that language learners who recognize how English words are created, by combining prefixes, suffixes, and roots, tend to have more words and comprehend text better. Welkes (2008:19) states that the internal structure of words by focusing on prefixes, suffixes, and roots will not only improve their knowledge base of words meanings, but actually improve their decoding or ability to 'sound out', unfamiliar words.

Hanson and Padua (2011:19) state that it is important for students to know how to use their understanding of prefixes, suffixes, and root or base words to unlock the meaning of words. Rasinski, et. al. (2008:21) state that by separating and analyzing the meaning of a prefix, suffix, or other word root, students can often unlock the meaning of an unknown word. Based on these statements, it can be stated that students will be able to know how to increase their vocabularies by applying affixation strategy. Knowledge of affixation strategy makes familiar words more interesting and unfamiliar words become familiar. It is easier to 
improve vocabulary by affixation because from just one word, it can gain many words with different part of speech than by memorizing each word separately.

\section{Research Methods}

\subsection{Research Design}

In line with the goal of this study to improve the students' vocabulary mastery by using affixation strategy, the research design was in the form of Classroom Action Research (CAR). Burns (2010:5) states that action research is research carried out by the teacher of the course, mainly with the purpose of solving a problem or improving the teaching or learning. Aaction research is carried out by teachers in their context, in their classrooms. Teachers identify a problem or an area they wish to improve and based on theory or experience or a hypothesis they think of an intervention. They document the intervention and results of it. If the results are positive, they could lead to the dissemination of the information. If not, the cycle may be reviewed.

Classroom Action Research consists of four phases in a cycle, they are: planning, action, observation, and reflection. This research followed the four steps of classroom action research model proposed by Kemmis and McTaggrat in Burns (2010:9):

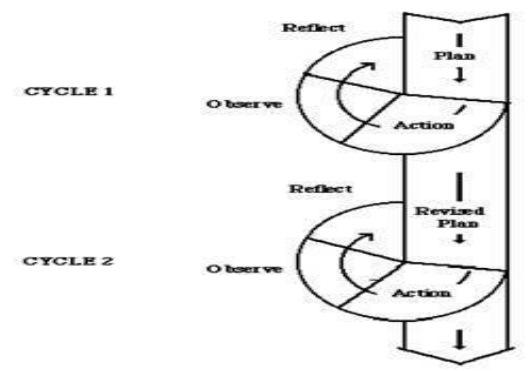

Figure 1. Cyclical Classroom Action Research (CAR) based on Kemmis and McTaggrat in Burns (2010:9)

\subsection{Location, Subject, and Time of Research}

The research was conducted at SMP Santo Petrus Medan which is located on Jalan Luku No.1 Simpang Pos, Kwala Bekala, Medan Johor, Kota Medan, Sumatera Utara 20146, Indonesia. The subject of research was the ninth grade students of SMP Santo Petrus Medan. The class consists of 30 students, 19 males and 11 females. The cycle I and cycle II were carried out on May and July in the second semester in the academic year of 2017/2018.

\section{Discussion}

\subsection{Data Analysis}

This chapter presents the data gathered from the actions. The data consists of cycle I and cycle II. The tests are given to know the students' vocabulary mastery improvement after they are taught with affixation strategy. The quantitative data are in the form vocabulary test. The following are the analysis of quantitative data:

\section{a. Analysis of Pre-test}

$$
\begin{aligned}
& M=\frac{\sum \mathrm{x}}{N} \times 100 \% \\
& \mathrm{M}=\frac{1040}{30} \times 100 \%=34.66 \%
\end{aligned}
$$


Based on the result of pre-test, all of the students cannot identify nominal, verbal, adjectival, and adverbial. There is no student passes Minimal Criterion Mastery whose value is 70 (seventy).

\section{b. Analysis of Cycle 1}

1. Total percentage of Nominal:

$\frac{\text { The students } \text { s }^{\prime} \text { maximum score of nominal }}{\text { Total of nominal }} \times 100 \%=\frac{182}{206} \times 100 \%=88.83 \%$

2. Total percentage of Verbal:

$\frac{\text { The students } s^{\prime} \text { maximum score of verbal }}{\text { Total of verbal }} \times 100 \%=\frac{110}{142} \times 100 \%=77.46 \%$

3. Total percentage of Adjectival:

$\frac{\text { The students }{ }^{\prime} \text { maximum score of adjectival }}{\text { Total of adjectival }} \times 100 \%=\frac{110}{270} \times 100 \%=40.74 \%$

4. Total percentage of Adverbial:

$\frac{\text { The students }{ }^{\prime} \text { maximum score of adverbial }}{\text { Total of adverbial }} \times 100 \%=\frac{69}{82} \times 100 \%=84.14 \%$

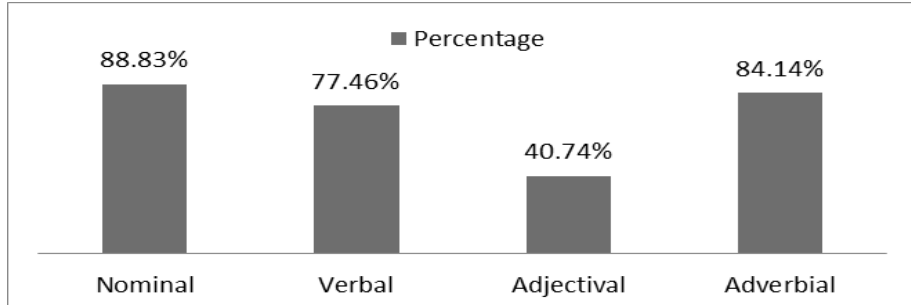

Figure 2. The Result of Students' Affixation in Cycle 1

The mean score in cycle 1:

$$
M=\frac{\Sigma \mathrm{x}}{N}=\frac{2804}{30}=93.46
$$

The class percentage who passes Minimal Criterion Mastery whose value is 70 (seventy) is calculated as follow:

$$
\begin{aligned}
& P=\frac{\mathrm{R}}{T} \times 100 \% \\
& \mathrm{P}=\frac{30}{30} \times 100 \%=100 \%
\end{aligned}
$$

The result of students' affixation in cycle 1 shows that the comparison percentage of the students' ability in nominal is $88.83 \%$, the students' ability in verbal is $77.46 \%$, the students' ability in adjectival is $40.74 \%$, and the students' ability in adverbial is $84.14 \%$. The students' highest percentage is nominal $(88.83 \%)$ and the students' lowest percentage is adjectival (40.74\%). It means that the students have a difficulty in adjectival based on the score of cycle 1 . Based on the result of cycle 1 , most of the students' still have a difficulty in adjectival. The writer continues to cycle 2 to improve the students' ability about adjectival.

Based on the calculation, the mean score of pre-test is 34.66 and the mean score of cycle 1 is $93.46 \%$ (pre-test < cycle $1=34.66<93.46$ ). It showed that there is an improvement of vocabulary mastery score between before the action and after the action. The class percentage is $100 \%$, it shows that all of the students (30 students) pass Minimal Criterion Mastery whose value is 70 (seventy). 


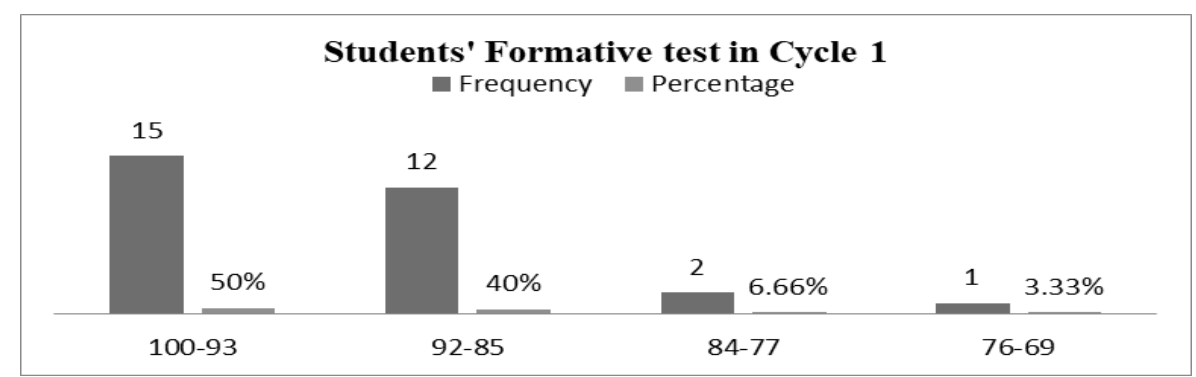

Figure 3. The Result of Students' Formative test of Class IX-1

The improvement from pre-test to cycle 1:

$$
\begin{aligned}
& \mathrm{P}=\frac{y 1-y}{y} \times 100 \% \\
& \mathrm{P}=\frac{93.46-34.66}{34.66} \times 100 \%=169.64 \%
\end{aligned}
$$

From the calculation, the writer concludes that between pre-test and cycle 1 have the significant difference, where the students' score of cycle 1 is higher than pre-test. It shows the implementation of affixation strategy can improve the students' vocabulary mastery.

\section{c. Analysis of Cycle 2}

1. Total percentage of Nominal:

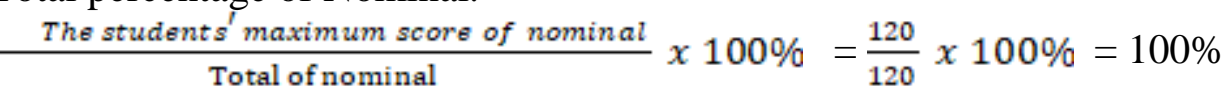

2. Total percentage of Verbal:

$$
\frac{\text { The students }{ }^{\prime} \text { maximum score of verbal }}{\text { Total of verbal }} \times 100 \%=\frac{84}{88} \times 100 \%=95.45 \%
$$

3. Total percentage of Adjectival:

$\frac{\text { The students } s^{\prime} \text { maximum score of adjectival }}{\text { Total of adjectival }} \times 100 \%=\frac{266}{404} \times 100 \%=65.84 \%$

4. Total percentage of Adverbial:

$\frac{\text { The students maximum score of adverbial }}{\text { Total of adverbial }} \times 100 \%=\frac{112}{118} \times 100 \%=94.91 \%$

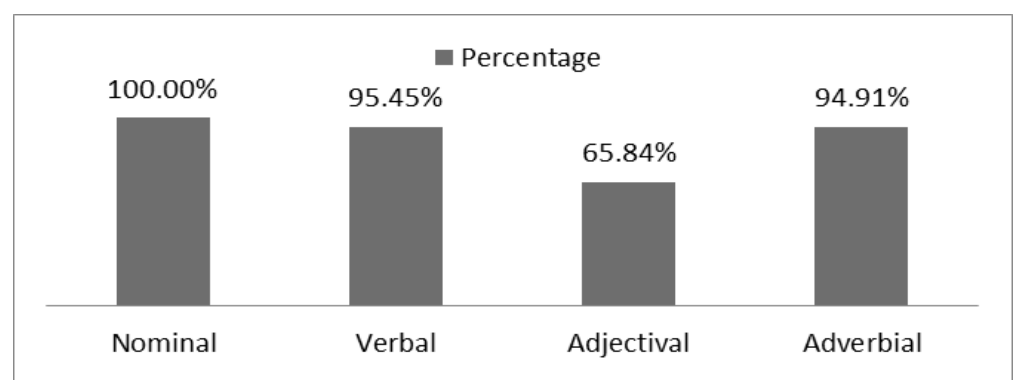

Figure 4. The Result of Students' Affixation in Cycle 2

The mean score of post-test in cycle 2:

$$
M=\frac{\Sigma \mathrm{X}}{N}=\frac{2920}{30}=97.33
$$

The class percentage who passes Minimal Criterion Mastery whose value is 70 (seventy) is calculated as follow:

$$
P=\frac{\mathrm{R}}{T} \times 100 \%
$$




$$
\mathrm{P}=\frac{30}{30} \times 100 \%=100 \%
$$

The result of students' affixation in cycle 2 shows that the comparison percentage of the students' ability in nominal is $100 \%$, the students' ability in verbal is $95.45 \%$, the students' ability in adjectival is $65.84 \%$, and the students' ability in adverbial is $94.91 \%$. The students' highest percentage is nominal $(100 \%)$ and the students' lowest percentage is adjectival (65.84). Based on the result of post-test, the progression of students in learning adjectival in cycle 2 is increased from $40.74 \%$ in cycle 1 to 65.84 in cycle 2 . It indicates that there is an improvement of the revises plan that have done before in cycle 1, especially the students' ability in learning adjectival.

Based on the calculation, the mean score of pre-test is 34.66 and the mean score of post test is 97.33 (pre-test < post-test $=34.66<97.33 \%$. It shows that there is an improvement of vocabulary mastery score between before the action and after the action. The students' vocabulary mastery score are increased in cycle 2 . The class percentage is $100 \%$, it means that all of the students (30 students) pass Minimal Criterion Mastery whose value is 70 (seventy).

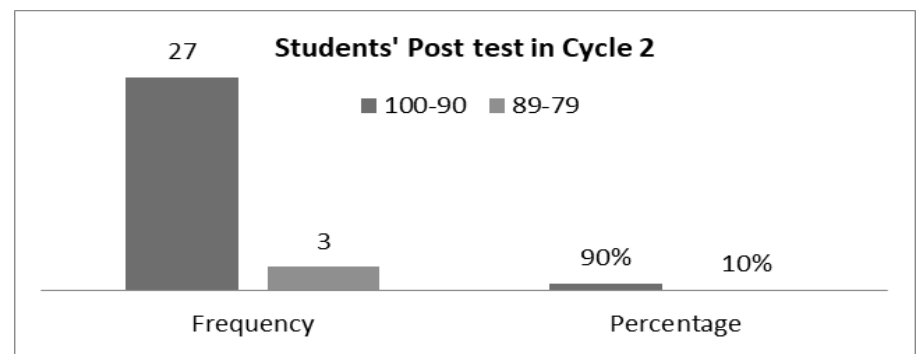

Figure 5. The Result of Students' Post-test of Class IX-1

The improvement from pre-test to post-test:

$$
\begin{aligned}
\mathrm{P}= & \frac{y 2-y}{y} \times 100 \% \\
\mathrm{P} & =\frac{97.33-34.66}{34,66} \times 100 \%=180.81 \%
\end{aligned}
$$

From the calculation, the writer concludes that between pre-test and post-test have the significant difference, where the students' score of post-test is higher than pre-test. It shows the implementation of affixation strategy can improve the students' vocabulary mastery. The following table is the comparison of the students' improvement of vocabulary mastery of pretest, formative test cycle 1 , and post-test cycle 2 .

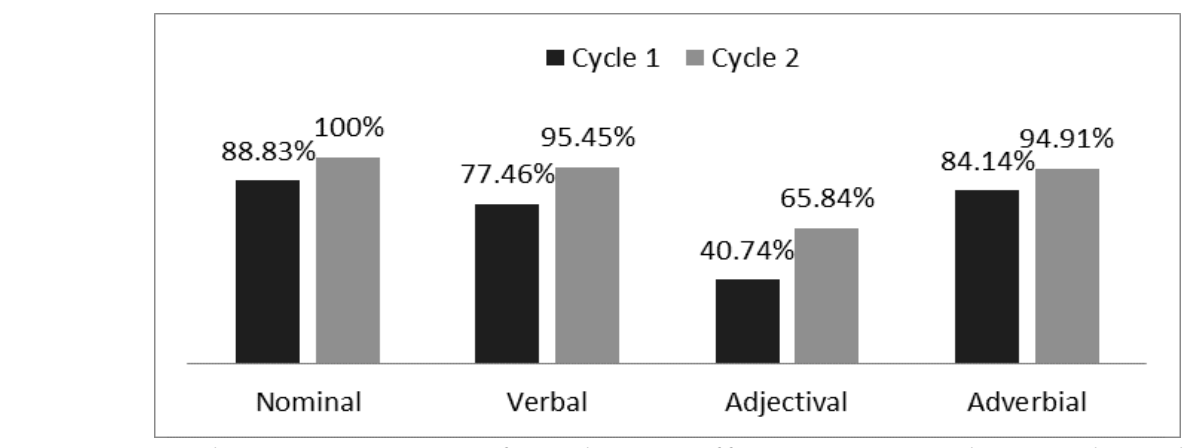

Figure 6. The Comparison of Students' Affixation in Cycle 1 and Cycle 


\subsection{Discussion}

Based on the analysis of data, the results of research are described as follows:

First, the result of each test is described as follows: At pre-cycle, the mean of pre-test score of IX-1 is 34.66 and it is relatively low. Knowing that vocabulary mastery is one important language component, therefore this problem is immediately solved. At the first cycle, the mean score is 93.46. The mean score of cycle 1 is much higher than the mean score of pre-test (93.46 > 34.66). All of the students (30 students) pass Minimal Criterion Mastery whose value is 70 (seventy). The comparison of students' percentage in nominal is $88.83 \%$, verbal is $77.46 \%$, adjectival is $40.74 \%$, and adverbial is $84.14 \%$. The students' highest percentage is nominal $(88.83 \%)$ and the students' lowest percentage is adjectival $(40.74 \%)$. Based on the result of affixation, the students have a difficulty in adjectival. The improvement of students' pre-test to the students' formative test in cycle 1 is $169.64 \%$. It shows that there is a significant improvement from pre-test to formative test in cycle 1 .

At the second cycle, the mean score is 97.33 . The mean score of post-test in cycle 2 is higher than the mean score of pre-test $(97.33 \%>34.66 \%)$. All of the students (30 students) pass the Minimal Criterion Mastery whose value is 70 (seventy). The comparison of students' percentage in nominal is $100 \%$, verbal is $95.45 \%$, adjectival is $65.84 \%$, and adverbial is $94.91 \%$. The students' highest percentage is nominal $(100 \%)$, and the students' lowest percentage is adjectival (65.84\%). The students' result in adjectival is increased from $40.74 \%$ in cycle 1 to $65.84 \%$ in cycle 2 . It indicates that the revises plan of affixation material in cycle 1 is effective. The improvement of students' pre-test to the students' post-test in cycle 2 is $180.81 \%$. It shows that cycle 2 can give a significant improvement than cycle 1 .

Based on the data analysis of study, it reveals that affixation strategy is effective to improve the students' vocabulary mastery of Class IX-1 of SMP Santo Petrus Medan in the academic year of 2017/2018.

\section{Conclusion}

Based on the score of Class IX-1, which is chosen as the subject of study, the students' score in pre-test is 34.66. It is in the low category because Minimal Criterion Mastery is 70. The students also cannot identify nominal, verbal, adjectival, and adverbial. Then the writer conducts cycle 1 and the mean score of pre-test is improved to 93.46 in cycle 1. In cycle 1 , the comparison percentage of nominal is $88.83 \%$, verbal is $77.46 \%$, adjectival is $40.74 \%$, and adverbial is $84.14 \%$. The students' highest percentage is nominal $(88.83 \%)$ and the students' lowest percentage is adjectival (40.74\%). Furthermore, for getting the better mean score and increasing the students' ability in adjectival, cycle 2 is conducted and the mean score is increased to 97.33 . In cycle 2, the comparison percentage of nominal is $100 \%$, verbal is $95.45 \%$, adjectival is $65.84 \%$, and adverbial is $94.91 \%$. The students highest percentage is nominal $(100 \%)$, and the students' lowest percentage is adjectival $(65.84 \%)$. The students' result in adjectival is increased from $40.74 \%$ in cycle 1 to $65.84 \%$ in cycle 2 . It indicates that the revises plan of affixation material in cycle 1 is effective. All of the students pass Minimal Criterion Mastery whose value is 70 (seventy). 


\section{References}

Adams, V. 2014. Complex Words in English. New York: Routledge Taylor and Francis Group.

Adebileje, A.O. 2013. A Comparative Description of Affixation Processes in English and Yoruba for ESL Pedagogy. International Journal of Theory and Practice in Language Studies, 3(10), 1756-1763.

Adeniyi, et. al. 2010. English Morphology. Nigeria: National Open University of Nigeria.

Bhatti, et. al. 2016. Improving Vocabulary through Affixes at Secondary Level. International E-Journal of Advances in Social Sciences, 2(6), 728-732.

Burns, A. 2010. Doing Action Research in English Language Teaching. New York: Routledge Taylor and Francis Group.

Cain, K. 2010. Reading Development and Difficulties. BPS Blackwell: Great Britain.

Daller, et. al. 2016. Language Dominance in Bilinguals: Issues of Measurement and Operationalization. Cambridge: Cambridge University.

Dechaine, et. al. 2012. Linguistics for Dummies. Ontario: John Wiley and Sons Canada.

Denham, K., \& Lobeck, A. 2010. Linguistics for Everyone. Boston: Wadsworth Cengage Learning.

Hair, L.M.W. 2008. Addressing Word Poverty and Comprehension through Text Talk Direct Instruction Method. Baltimore MD: Paul Brokes Publishing Company.

Hanson, S., \& Padua, J.F.M. 2011. Teaching Vocabulary Explicitly. Honolulu: Pacific Resources for Education and Learning.

Hasani, et. al. 2014. The Effect of Number of Affixes on Vocabulary Learning of Iranian Intermediate EFL Students. International Journal of Language Learning and Applied Linguistics World, 5(3), 84-96.

Haspelmath, M., \& Sims, A.D. 2010. Understanding Morphology. London: Hodder Education.

Hatch, E., \& Brown, C. 2001. Vocabulary, Semantics, and Language Education. Cambridge: Cambridge University.

Hendrty et. al. 2010. X-Kit Reference: English. Capetown: Person Education South Africa.

Huddleston, R., \& Pullum, G.K. 2005. A Students' Introduction to English Grammar. Cambridge: Cambridge University.

Injeeli, P. 2013. Minds Your Words: Master the Art of Learning and Teaching Vocabulary. Singapore: Trafford.

Jackson, H., \& Amvela B. 2007. Words, Meaning, and Vocabulary: An Introduction to Modern English Lexicology. London: Continuum.

Karimkhanlooei, G., \& Maboudi, B. 2017. Affixation Knowledge Strategy in Teaching English Vocabulary for Medicine. International Journal of Language in India, 17(1), 72-90.

Katamba, F. 2005. English Words. London: Taylor and Francis e-Library.

Kim, C. 2013. Vocabulary Acquisition with Affixation: Learning English Words based on Prefixes and Suffixes. International Journal of Second Language Studies. 31(2), 43-80.

Kligner, et. al. 2015. Teaching Reading Comprehension to Students with Learning Difficulties. London: The Guilford.

Lee, et. al. 2015. An Introduction to Korean Linguistics. New York: Routledge Taylor and Francis Group.

Lems, et. al. 2010. Teaching Reading to English Language Learners. New York: The Guilford. 
Lieber, R. \& Stekauer, P. 2014. The Oxford Handbook of Derivational Morphology. Oxford: Oxford University.

Lindstrom, F. 2007. Adventures in Phonics: Level B. Illinois: Christian Liberty.

Lutratrio, C. 2005. Key Spelling: Teacher's Handbook. Oxford: Harcourt Education.

Nation, I.S.P. 2001. Learning Vocabulary in Another Language. Cambridge: Cambridge University.

Nijakowska, J. 2010. Dyslexia in the Foreign Language Classroom. London: Short Run.

Oakhill, et. al. 2015. Understanding and Teaching Reading Comprehension: A Handbook. Routledge: Taylor and Francis Group.

Oz, H. 2014. Morphology and Implications for English Language Teaching: Linguistics for English Language Teaching Studies. Ankara: Ani Publishing.

Peukert, H. 2015. Transfer Effects in Multilingual Language Development. Amsterdam: John Benjamins Publishing.

Plag, I. 2002. Word Formation in English. Cambrige: Cambridge University.

Rasinski, et. al. 2008. Greek and Latin Roots: Keys to Building Vocabulary. Huntington Beach: Shell Education.

Rhoades, J. 2004. Rhoades to Reading Level IV: Teaching Guide. Alta Loma: The Reading Company.

Thornbury, S. 2002. How to Teach Vocabulary. London: Pearson Education Limited.

Traxler, M.J. 2012. Introduction to Psycholinguistics: Understanding Language Science. Malden: Wiley Blackwell.

Vadasy, P.F., \& Nelson, J.R. 2012. Vocabulary Instruction for Struggling Students. London: Guilford.

Verspoor, M., \& Sauter, K. 2000. English Sentence Analysis: An Introductory Course. Amsterdam: John Benjamins Publishing Company.

Welkes, T.R. 2008. Baron's SAT Strategies for Students with Learning Dissabilities. Hauppauge: Baron Educational Series. 